\title{
Internationalization vs. family ownership \\ and management: the case of Portuguese wine firms ${ }^{1}$
}

\section{STRUCTURED ABSTRACT}

Purpose: The objective of this paper is to empirically examine the relationship between the firms' ownership and control structure and their export performance. The literature is traditionally focused on the relation between firms' performance and internationalization, with the relation between ownership and control structure with internationalization being much less studied, particularly in the context of family firms.

Design/methodology/approach: We focus our study on the Portuguese wine firms due to their increasing importance in the Portuguese economy and in the promotion of the country's exports and image abroad. It is used a balanced panel data sample of 82 firms for the period from 2011 to 2015 and applied a random effects model and a Tobit specification.

Findings: The degree of family involvement shows a negative and significant relationship with internationalization, meaning that family firms that intend to internationalize should be open to receive external managers with international experience and increase their internal competencies in order to enhance internationalization.

Originality/value: This paper extends the literature since assesses, at the light of the agency theory, the presence of differences in the internationalization degree and export intensity between family firms that are managed and controlled by the owners and family firms that are managed by non-family members, with an application to a less studied sector and country.

Key-words: Wine industry, Internationalization, Ownership structure, Family firms, Agency theory

\section{Introduction}

Internationalization represents a natural development for many firms but for others it constitutes a difficult barrier to surpass. International business literature has advanced a set of strategies and determinants of international diversification and trade (Buckley and Casson, 1976; Dunning, 1980; Rugman, 1981; Hennart, 1982), highlighting the associated benefits and costs (Rugman, 1976; Zaheer, 1995). The most common forms of firms' internationalization, particularly for Small and Medium Enterprises (SMEs) are based on a low commitment perspective focusing on exporting, which offers greater

\footnotetext{
1 Published as: Pacheco, Luís (2017), "Internationalization vs. family ownership and management: the case of Portuguese wine firms", International Journal of Wine Business Research, vol 29, n 2, DOI: 10.1108/IJWBR-10-2016-0034
} 
flexibility and requires fewer resources than other ways of entering foreign markets (Leonidou, 2004; Leonidou et al., 2007).

This paper is not focused on the different strategies of internationalization but specifically on the association of internationalization with ownership structure. While managers try to maximize their utility being more prone to internationalization, shareholders are more selective and conservative, with this agency problem being probably more acute in family firms. The impact of corporate governance on firms' strategic decision-making and performance has been well documented in the literature (Shleifer and Vishny, 1986; Buck et al., 2003) but their effects on firms' export performance have been less studied. Exporting strategy, as a risky adventure in the international markets, is highly associated with corporate governance factors such as ownership structure (George, Wiklund and Zahra, 2005; Filatotchev, Stephan and Jindra, 2008).

Since theoretical predictions are not straightforward, the objective of this paper is to study if the level of internationalization of the Portuguese wine industry is affected by the firms' classification as a family firm and the capacity of the family to control the firms' management. Some control variables are also added to explain internationalization, namely leverage, firm size and firm age. We extend the current literature, since this is an issue still less studied, particularly in the Portuguese context. Considering a balanced panel data of 82 Portuguese wine SMEs for the period from 2011 to 2015 , with a total of 410 observations, we conclude that family owned firms with internal management show significant lower measures of internationalization.

\section{Literature review}

Due to globalization and export growth, a robust export performance is increasingly a critical factor for a firm general performance and survival. For firms, entering the export market constitutes a high-risk decision that encompasses sunk costs, revenue volatility due to exchange rate movements, limited knowledge of external market conditions, local competition and cultural assimilation (Rocco, 1996; George et al., 2005). Different firm-specific characteristics such as size, age and product diversification have been shown to be associated with SMEs internationalization (Graves and Thomas, 2004; Kontinen and Ojala, 2010). In this paper, departing from an agency theoretical setting, 
our unique objective is to study the impact of the ownership and management structure on the internationalization level of wine firms.

\subsection{Ownership structure and export performance}

According to the corporate governance literature, a firm's ownership structure affects its performance (Anderson and Reeb, 2003). Ownership structure is here defined as the distribution of ownership stakes with regard to capital and the associated votes or controlling power.

Agency theory explains the consequences of the separation of ownership and control. While a firm's owners are interested in maximizing firm value, the managers pursue the maximization of their own utility, that is, their current and future income and other nonmonetary rewards (Jensen, 1986; Harris and Raviv, 1991; Aggarwal and Samwick, 2003). So, the concentration of ownership in a few hands increases the incentives that owners have to monitor managers or giving managers incentives to act according to shareholders' interests (Jensen and Meckling, 1976; Denis, Denis and Sarin, 1997, 1999). There is substantial evidence that the behavior of manager-controlled firms is different to the behavior of owner-controlled firms, thus supporting agency theory. For example, manager-controlled firms are more likely to maximize sales than profits and be more diversified (Amihud and Kamin, 1979; Amihud and Lev, 1981), both factors with a positive impact on internationalization. For instance, Amihud and Lev (1981) argue that diversification constitutes a mean to reduce managers' employment risk, stabilizing a firm's income streams and preventing bankruptcy. The issue of international diversification arises inevitably when talking about firm's diversification, since international diversification increases a firm's systematic risk due to factors such as political risk, foreign exchange risk and asymmetric information between multinational firms and domestic competitors. Kwok and Reeb (2000) elaborate this argument by noting that the risk reduction of international diversification depends on the firm's home and target conditions and Zahra, Neubaum and Naldi (2007) suggest that ownership and governance structures can be aligned to promote SMEs efforts in building knowledge-based resources necessary for internationalization. In particular, Zahra et al. (2007) emphasize the fact that having more "outsiders" in the firm's board can better allign the different stakeholders' interests, thus promoting internationalization processes. Oesterle, Richta and Fisch (2013) study the influences of ownership concentration on internationalization, concluding that the relationship is non-linear. To 
test that hypothesis, they use panel data for 102 large German manufacturing firms from 1990 to 2006. At the initial stage of international diversification, as firms expand abroad, their financing needs can only be met using short-term debt as they may find it difficult to raise long-term debt due to investor perceived higher information asymmetries. Once these firms have established themselves in the host market and the investors feel safe in investing long-term in these multinational corporations, these firms reduce their dependence on short-term debt and raise long-term debt instead. This logic further implies that as multinational corporations expand in the host markets they are able to raise more long-term debt yielding a positive relationship between long-term debt and the degree of international diversification. So, as summarized by Oesterle et al. (2013), international diversification driven by the managers' motive to reduce risk constitutes a classical agency theory problem of conflicting interests between shareholders and managers, where if managers are not constrained by shareholders they will follow a sub-optimal diversification strategy.

Whether ownership concentration is beneficial or harmful for corporate performance is ultimately an empirical question since the literature fails to uncover a definitive pattern. Nevertheless, the effect of ownership structure on the firm's export performance has been a less studied topic, at least in Portugal or in specific sectors of activity.

\subsection{The idiosyncrasies of family firms}

Normally, international business theory is focused on large corporations or SMEs. A particular type of firm less studied in terms of internationalization and corporate governance are family firms, which are the dominant form of corporate governance in many countries (European Commission, 2009). Although there is no general consensus on the definition of a family firm (Kontinen and Ojala, 2010), such firms can be defined as a business in which members of one or various families share, to a great extent, capital, management responsibilities, and the intention of passing the business to future generations (Astrachan, Klein and Smyrnios, 2002). According to the European Commission (2009), more than $60 \%$ of European firms are familiar firms, accounting for $40 \%$ to $50 \%$ of the employment in the private sector. In Portugal, according to the Portuguese Families Businesses Association (www.empresasfamiliares.pt), 70\% to $80 \%$ of the Portuguese firms, and probably more than $60 \%$ of GDP and $50 \%$ of employment is ensured by firms "whose property is, total or partially, in the hands of one or more families, with the family having the control over the firm's management". It is 
necessary to clarify that although many family firms are considered in the category of SMEs, they are not all, since there are also large-sized family firms.

Family firms add a dimension to the shareholders vs. managers relation described above since family members' interests could not be the same as those of their non-family counterparts (Claver, Rienda and Quer, 2009). Also, since often in family firms owners are also managers, should those firms have higher levels of internationalization? Family firms possess some strengths favoring internationalization, namely their experience and knowledge of the business, their solid values and group-belonging culture and their long-term perspective (Swinth and Vinton, 1993; Tsang, 2002 and, for literature surveys, see Kontinen and Ojala, 2010 and Pukall and Calabrò, 2014). However, some limitations are succession turbulence, weak organizational structure, lack of professionalism and difficulties in financing (Graves and Thomas, 2004; Claver et al., 2009).

Concentrated ownership means higher risk and sunk costs, so firms controlled by the family would look to international markets as a way to diversify risk (Denis, Denis and Yost, 2002). Also, the concentration of a substantial block of shares in the hand of a single owner (the family) increases the chances that managers will act in the interest of the owners. Yet, since family members pertaining to the managerial board could lack the necessary skills to internationalize the firm, and the qualified workers decline to join family firms due to the lower perspectives to build a career, family firms could be less internationalized (Graves and Thomas, 2006). In the context of the agency theory, nonfamily managers have the incentive to assume riskier projects, including increasing the firm's presence in foreign markets (Anderson and Reeb, 2003). Since the personal wealth of family members is invested in the firm, family controlled firms present higher risk aversion and concerns with survival and transmission to the next generation, so that the effect of the firm's ownership structure on internationalization becomes a relevant topic though with mixed empirical evidence (e.g., Zahra, 2003; Zahra et al., 2007; Carr and Bateman, 2009; Kontinen and Ojala, 2011; Sciascia et al., 2012; Majocchi and Strange, 2012; Mitter et al., 2014). For instance, Kontinen and Ojala (2011) find that the small size and flexibility of management teams in family firms allow them to react quickly to new international opportunities, whereas Gomez-Mejia, Makri and Kintana (2010) conclude that family firms exhibit lower levels of internationalization than nonfamily firms due to their concern with preserving the family control of the business. An important point is to distinguish between family ownership and family involvement. For 
instance Zahra (2003) argues that the positive effect of family ownership on internationalization is reinforced when family members also participate in the management of the business. Mitter et al. (2014) evidence an inverted U-shaped relationship between family influence and internationalization. Thus, concerning internationalization, the advantages of being a family firm are highest when the family's ownership share and involvement in management and governance boards is not too extensive. Nevertheless, albeit without a clear prediction, the literature points generally to the idea that family firms are less internationalized than non-family firms or, at least, their internationalization processes are slower. On the other hand, family involvement in the management seems to have a positive effect in internationalization (Zahra, 2003; Graves and Thomas, 2004; Menendez-Requejo, 2005; Fernández and Nieto, 2005).

Regarding leverage, some studies show that family firms prefer going into debt before increasing capital to finance their investments, thus avoiding the entry of non-family shareholders (Anderson, Mansi and Reeb, 2003). However, other studies show that family firms prefer to be more prudent, not going into debt in order to avoid losing their independence to creditors (López-Garcia and Aybar-Arias, 2000). Given that family firms have specific concerns in terms of privacy, control and generational transition, they tend to prefer internal financing policies, favoring the reinvestment of their own funds to capital increase or long-term debt (Gallo, Tàpies and Cappuyns, 2004; Blanco, De Quevedo and Delgado, 2009), nevertheless, their attitude towards debt could be changed as generations, managers and the business as a whole evolves (Lussier and Sonfield, 2009). According to Miller, Le Bretton-Miller and Lester (2010), family owners and managers, influenced in their decisions by shareholders, tend to be more conservative than non-family firms, trying to minimize risk through investment reductions in $\mathrm{R} \& \mathrm{D}$, lower debt levels and lower degrees of internationalization, since this is a process that requires great effort and capital to be carried out.

\subsection{Why study the wine sector?}

Empirical efforts on factors influencing product diversification and internationalization have shown that industry classification is a relevant factor, since products of different industries may have different properties concerning their international marketability. For this type of research, and since we do not intend to perform intra-industry comparisons, it is better to study a particular sector in order to control possible idiosyncrasies of different industries. This focus answers a call from Kontinen and Ojala 
(2010), suggesting that are needed studies of family firms' internationalization focused on specific (non-manufacturing) industries. To the best of our knowledge the wine sector has never been the object of such a study, a factor which motivates the present research. For instance, Remaud and Couderc (2006) and Maurel (2009) analyze the determinants of export performance for wine firms, albeit do not focus ownership and control issues. Muecke (2008) analyzes the impact of the structure of social capital on the decision to start international activities and, recently, Francioni, Vissak and Musso (2017) examine how network relationships influence the internationalization of small Italian wine producers.

The wine sector constitutes a source of proud and reputation for Portugal, a country with a high diversity of producing regions, with 31 Protected Designations of Origin and an extraordinary diversity of castes. Wine exports in value have grown in 2015 for the sixth consecutive year, while the sector also consolidated its position in terms of volume and value in the domestic market. According to the Portuguese Institute of Vine and Wine (www.ivv.min-agricultura.pt) the average annual total production of wine was around 7 million hectoliters in 2015, being exported 2,8 million hectoliters with a value around $€ 737$ million. Portugal is the ninth world exporter, with France, United Kingdom, Angola and the United States being the four main markets, either in terms of volume as in terms of value. Notice that, whereas in volume there is a balanced distribution of exports between the European Union (EU) market and the outside EU market, in terms of value the EU market accounts for $57 \%$ of the exports. A majority of firms in this sector are familiar and mature firms, with ownership and control passing between generations, justifying the choice of this sector. Additionally, the sector faces a limited domestic market and the need to find new external markets, where some increasingly competitive new producers are present. These challenges are also faced by wine producers around the globe, so the conclusions from this paper could potentially be generalized to other countries.

Following the literature review made above, and focusing on the Portuguese wine sector SMEs, we can now state the hypotheses tested in this paper:

H1: Family firms present a lower degree of internationalization when compared to non-family firms 
H2: Family firms where managers belong to the family present an higher degree of internationalization

H3: Firms with higher debt levels present a lower degree of internationalization

H4: Larger firms present an higher degree of internationalization

H5: Older firms present an higher degree of internationalization

\section{Definition of variables, data and methodology}

\subsection{Definition of variables}

Concerning the variable "international diversification", studies reported in the literature use different measures, so that a consensus is still lacking on the best or true measure of international diversification (Majocchi and Strange, 2012). Some possible measures are the foreign sales percentage, the foreign tax ratio, the number of countries in which the firm operates, entropy measures of the firm's geographical diversification and composite indexes. Due to data availability, most of the studies for European firms measure the presence in outside markets as the ratio of exports to countries outside EU over total sales and the presence in the EU market is measured as the ratio between exports to EU countries and total sales. The use of a uni-dimensional measure such as the ratio of foreign sales to total sales does not take into account the geographical distribution of sales, i.e., whether or not they are geographically well balanced in major world markets (Rugman and Verbeke, 2004). In this paper, besides the traditional measure of export-intensity (total exports as a percentage of total sales, here defined as variable EXP), it would be used a measure of entropy, which accounts for the dispersion of a firm's international sales.

Following Majocchi and Strange (2012), albeit with some limitations due to data availability, we look at the distribution of total sales in three main geographical areas (Portugal, the European Union and the rest of the world). Using this classification, we develop a measure of international diversification (INT) based on the Kim (1989) entropy index that has been extensively used in recent studies on international diversification (e.g., Hitt et al., 2006; Majocchi and Strange, 2012).

$$
\text { Index of international diversification }(\mathrm{INT})=\sum_{\mathrm{j}=1}^{3} \mathrm{x}_{\mathrm{j}} \ln \left(\frac{1}{\mathrm{x}_{\mathrm{j}}}\right)
$$

The subscript $\mathrm{j}$ defines one of the three markets and $\mathrm{x}_{\mathrm{j}}$ is the percentage of sales realized in market $\mathrm{j}$. The natural logarithm of the inverse of the sales realized in every market is 
the weight given to each geographical segment. The entropy measure will equal zero for firms that have all their sales concentrated in one region, and will reach a maximum value of 1,098 for firms with exactly the same share of sales in each of the three defined areas. Nevertheless, as stated by Majocchi and Strange (2012), such a measure also has some weaknesses: it is not expected that a firm's level of international sales to be evenly distributed between destiny areas, and an ideal measure of internationalization should not only measure the dispersion of foreign sales, but also their level.

A dummy variable for family firms is used to differentiate between family and nonfamily firms. A family firm is defined as a firm where different family members have a total ownership/capital stake above $50 \%(\mathrm{FAM}=1)$, while those with a lower percentage are classified as non-family firms $(\mathrm{FAM}=0)$. The intention is, therefore, to analyze if family ownership has a negative relationship to international diversification and export-intensity and whether or not the behavior of these firms differs from that of non-family firms. A second dummy variable accounts for the fact that family members are directly involved in the top management (e.g., CEO or Chairman of the Board) of the firm $(\mathrm{INV}=1)$, being expected a positive effect in the degree of internationalization. Even though our paper is focused on the relation between ownership structure and internationalization, we will use as control a set of four variables traditionally used in studies about internationalization determinants: short-term and long-term debt and firm size and age.

Concerning the control variables, the debt level of the firm is measured as total debt $(\mathrm{TD}=$ Total liabilities / Total assets $)$ and its subdivision in short-term and long-term debt (respectively, Current Liabilities / Total Assets and Non-current Liabilities / Total Assets). The debt ratios explain how the firm can finance its activity with its own resources and what degree of independence lies with external agents. In line with the majority of the literature cited above, we expect a negative relationship between debt levels and internationalization. Firm size (SIZ) is measured by the logarithm of total assets. A firm's size can influence its internationalization for two reasons. First, larger firms are more likely to engage in international operations due to scale advantages that enable them to overcome potential financial and human resource barriers arising from foreign activities (Bausch and Krist, 2007; Calof, 1994, Manolova et al., 2002). Second, firm size could have a negative effect on ownership concentration, and thus a negative effect on internationalization, since more capital is needed to own the same percentage of a large firm as compared to a small one (Seifert, Gonenc and Wright, 2005). 
Nevertheless, our research hypothesis is based on that first reason. Finally, concerning the variable age (AGE), measured as the number of years since the firm's birth, older firms should possess a greater stock of knowledge and experience, which has a positive impact on internationalization (Johanson and Vahlne, 1977). Also, associating an older firm with a second or third generation family firm, firm age should be positively related to internationalization since the second and the third generations are more likely than the founding generation to start exporting in family SMEs (Fernández and Nieto, 2005). For instance, Menendez-Requejo (2005) finds that successive generations have a positive influence on the internationalization of family firms in Spain.

\subsection{Data}

In this paper we use a sample of SMEs from the wine sector, where firms are classified as small or medium according to the Commission Recommendation 2003/361/EC criteria. The dependent variables are the index of international diversification and the measure of export-intensity and the independent variables represent the firm's internationalization determinant factors according to the previously stated hypothesis.

Our objective is to analyze a sample of SMEs from the wine sector (pertaining to CAE 1102 of the Portuguese Classification of Economic Activities), obtained from SABI (Sistema de Análise de Balanços Ibéricos), a finnancial database powered by Bureau van Dijk. The database includes data for 200 wine sector firms, with a turnover over 1.400 $\mathrm{M} €$, total assets around 3.350 M€ and 7.230 employees. Applying the criteria for SMEs definition, excluding 36 micro firms (which employ fewer than 10 persons and whose annual turnover and/or annual balance sheet does not exceed $2 \mathrm{M} €$ ) and considering only firms with a 5 year period of complete data from 2011 to 2015 and excluding firms with debt ratios above $100 \%$ or negative or liabilities greater than assets, we obtained a balanced panel data of 82 SMEs distributed by all Portuguese wine producing regions. The sample is representative of the sector, accounting for 2.549 employees, a turnover near $400 \mathrm{M} €$ and total assets of $871 \mathrm{M} €$ in 2015. The sample only has 10 medium firms and, applying the criteria explained above, 51 firms can be considered familiar firms, of which 44 have the family directly involved in the top management. The sample's average values in 2015 for total debt, size and age are, respectively, 53\%, 8,95 and 38,6 years, with family firms presenting similar values. Concerning exports, in 2015 firms in the sample present average values for INT and EXP (i.e., total exports as a percentage 
of total sales) of, respectively, 0,67 and 0,39, exporting around $40 \%$ of their production, equally divided between the EU and non-EU markets. In relation to the family firms' subset, when compared to non-family firms the degree of internationalization seems rather lower, presenting values of 0,62 and 0,35 for, respectively, INT and EXP and a slightly higher percentage of sales concentrated in the domestic market.

(Insert Table 1 here)

Besides the average values for 2015, Table 1 also presents the values for 2011 and the correlation matrix of the variables used in this paper. According to Gujarati and Porter (2008), when the correlation coefficients are above $50 \%$, the problem of collinearity becomes significant. Observing the correlation coefficients between the independent variables and since the variables FAM and INV will not be used jointly, the problem of collinearity between explanatory variables will not be relevant.

\subsection{Methodology}

In order to attain our research objective we apply two different econometric techniques. First, a panel data methodology which can be estimated trough three different regression models: Pooled Ordinary Least Squares (POLS), Fixed Effects Model (FEM) and Random Effects Model (REM). Applying the Breusch-Pagan and Hausman tests to choose the most appropriate regression technique, the Breusch-Pagan test leads to the rejection of the null hypothesis, indicating that REM is more appropriate than POLS and the Hausman test leads to the acceptance of null hypothesis that REM is preferable to FEM. As stated by Majocchi and Strange (2012), the use of a random effects approach is advisable since there are reasons to believe that not all relevant variables are included in our model, that is, some excluded potential explanatory variables may be constant over time but may vary between firms whilst others may be constant over firms but vary over time. Additionally, since the two dependent variables are left-censored (obviously, there are no values below zero for INT and EXP is defined between zero and one), we adopt a Tobit methodology (Gujarati and Porter, 2008). Tobit regressions are nonlinear therefore the coefficients should be interpreted with care and do not measure the real causal effect on the dependent variable. This effect is correctly 
measured only by the marginal effect however the coefficients maintain the significance and sign of the marginal effects, allowing the test of our hypothesis.

In the two methodologies we run the two dependent variables (INT and EXP) on the variables FAM and INV and the control variables total debt (TD, also divided in shortterm debt - STD and long-term debt - LTD), SIZ and AGE. The explanatory power of the REM model is given by the overall $\mathrm{R}^{2}$ and the significance of the Tobit regression is assessed by reference to the Wald $\chi^{2}$ statistic.

\section{Empirical results}

The regression results for the random-effects model are presented in the upper part of Table 2, where the dependent variables is the measure of internationalization (INT) or the export to sales ratio (EXP). The lower part of Table 2 presents the regression results for the Tobit Model.

(Insert Table 2 here)

The random-effects model results present a modest goodness of fit with a $\mathrm{R}^{2}$ around 9 and $4 \%$, respectively for the dependent variables INT and EXP, values that are in line with some previous papers. The Tobit regressions show comforting results for the overall indexes of goodness of fit ( $\chi^{2}$ and log-likelyhood ratio), suggesting that the overall specification of the model is good. We now analyze the results at the light of the different hypothesis.

With either of the two models it is not possible to confirm hypothesis 1, since all the regressions with the two different dependent variables yield a negative albeit nonsignificant coefficient for the variable FAM. This suggests that Portuguese family owned wine firms do not differentiate themselves from non-family owned firms in terms of international diversification and intensity. However, when we substitute FAM with INV, the results in the Tobit model present a negative and significant relation, suggesting that family members' exclusivity at the top management could mean a lower degree of internationalization. So, not confirming hypothesis 2 , the dominant involvement of the family in the firm impairs a higher degree of internationalization. This interesting result contradicts some previous literature (e.g., Zahra, 2003; Graves and Thomas, 2004) and deserves further attention, being discussed in the last section. 
The results yield a negative and significant relation between debt and internationalization. Albeit not presented, this relation is also significant when debt is divided into short and long term debt, thus confirming hypothesis 3. Less leveraged firms seem to be more export-oriented or higher levels of debt turn the internationalization process more difficult, which is a result also found by other authors (e.g., Majocchi and Strange, 2012). This result is in line with the predictions of agency theory, since a high level of leverage imposes a fixed financial commitment on the firm, reducing the free cash flows available to management and the possibilities to internationalize. Regarding family firms, a negative relation could be explained by the family's concerns with increased levels of financial risk and fears of losing control (Zahra, 2005).

The variable size is shown to exert a positive and significant impact in both measures of the export activity, which demonstrates that larger firms can afford the high costs of exporting. This result that confirms the positive relationship between resources and internationalization is more significant in the Tobit regression and confirms hypothesis 4. There are several studies finding a positive relationship between firm size and internationalization (e.g., Filatotchev et al., 2008; Majocchi and Strange, 2012).

The variable firm age was not deemed significant in any of the regressions, suggesting that firm age has no influence on foreign sales, thus not confirming hypothesis 5. Hence, the lower internationalization of family owned and controlled firms is not due to the fact that they are young, born global firms, since there seems to exist no difference in the degree of internationalization between younger and older firms. So, this result does not confirm the Uppsala model, which defends that internationalization is a gradual process (Johanson and Vahlne, 1977). Controlling for age also allows us to control for the possible differences in internationalization between founder-own family firms and second and third generation firms, which are likely to be older firms. Our insignificant age variable shows that older firms (and hence second, third generation family firms) do not have systematically lower degrees of internationalization.

Table 3 presents a comparison between the expected and observed relationships, where we can validate the different hypotheses that were tested in this empirical study.

(Insert Table 3 here)

\section{Conclusions, implications, limitations and future research recommendations}


Internationalization theories should not consider firms just as a value maximizing entity regardless of its owners. Different owners and managers have different risk attitudes, face different incentives and bring to the firm different resources, so similar firms, pertaining to the same sector, could present different degrees of internationalization. To date, at the light of agency theory, little empirical research has been conducted to identify the variables that foster family firms' internationalization decisions.

This exploratory paper contributes to fill that gap studying the differences between family firms that are managed and controlled by the owners and family firms that are managed by non-family members. We constructed a balanced sample of 82 firms from the wine sector for a period of 5 years, between 2011 and 2015, with a total of 410 observations. A set of control variables were used namely debt and firm size and age. Possibly, some of the differences found in this paper are due to the fact that several previous papers focused on small firms at very early stages of their life or large listed firms and used different measures of internationalization and classification as a familyfirm. Our sample is composed of mature SMEs, with an average age of 38 years, some of them export-oriented firms for several decades. The hypotheses tested in this paper have been tested in other different sectors and country samples being this paper, to our knowledge, the first one to test them for wine firms and in the Portuguese context.

The degree of family involvement showed a significant negative relationship with internationalization, meaning that those family firms in which the owner family exerts tighter control tend to diversify and export less, confirming previous results from Graves and Thomas (2004), Gomez-Mejia et al. (2010), Miller et al. (2010) and Sciascia et al. (2012). This result indicates that firms willing to increase their degree of internationalization should welcome the presence of external managers, focused on maximizing firm value, that bring to the firm the necessary skills and competencies to develop internationalization processes. Also, this result highlights the importance of providing family firms' members the necessary competencies to undertake an internationalization process, namely, specific training for the next generation, specialized consultancy and other state-support initiatives. In sum, the fact that family firms do not seem to present lower degrees of internationalization when compared to other firms, unless family members become involved in management, suggests that the research on governance should focus on the factor of real authority rather than formal authority. 
Regarding the main questions addressed in this paper, we can answer that: i) compared to other firms, family firms do not differ in terms of internationalization, but ii) the degree of internationalization depends negatively on the involvement of owners in management; iii) additionally, there is a significant negative relation between the level of debt and the degree of internationalization; iv) and, finally, there is a significant positive relation between the degree of internationalization and firm size, albeit a nonsignificant impact of firm age on internationalization.

Some limitations of this study should be mentioned: i) in the first place, firms' export activity is affected by many variables that were not considered (e.g., managerial labor and product markets, government incentives to internationalize, political and economic factors or even the personality of shareholders and managers), meaning that the results should be treated with caution; ii) secondly, the concept of family firm used in the literature is not homogeneous, being normally used a dichotomous characterization. Other authors present continuous measures, with indexes of familiness, such as the FPEC scale (Astrachan, Klein and Smyrnios, 2002) or the SFI formula (Klein, 2000; Mitter et al., 2014), which could explain the different results found and provide more insight into the non-significant effect for family-ownership. Future research on this topic should adopt a standard and consistent definition of family firm in order to allow the comparability of results; iii) third, the dataset comprises 82 firms, representing around one third of the Portuguese wine sector. Ideally, a larger number of observations and firms could result in more robust results. Notice that firms under analysis are the firms that survived a period of fierce competition and emergence of new international players in the sector; iv) finally, a factor that can limit the generalization of the results is that the study focuses only on the Portuguese wine sector. Also, the measures of internationalization used in the literature differ widely, leaving us with the question whether our results are dependent on the two measures used and on the specific context of the Portuguese wine firms. Notice that, it could be the highly demanding skills necessary to the internationalization of wine firms that are responsible for our results. Nevertheless, the limitations of the internal market and the small size of firms are characteristics also present in other wine-exporting countries, so our conclusions could perfectly be applied to other countries.

Analyzing our main results through the light of agency theory, we can argue that increased family control silences any voices that could counterbalance the family's perspective in strategic decision making, impairing the decision to internationalize. As 
proposed by Sciascia et al. (2012), this result suggests that family owners should consider opening equity to non-family capital providers as one way to reduce the stagnation effects that result from total control and foster exports. Also, increased training for the next generation, regularly monitoring the international environment and expand networks through the regular attendance of international fairs, are some activities that could foster internationalization and enhance family firms' sustainability and development.

Our results call for further research, suggesting that the internationalization level depends heavily on other factors. So, further research should, inter alia, (i) introduce qualitative variables, for instance, consider problems in terms of access to internationalization incentives and consider internal factors such as succession issues, product positioning, marketing and brand management and the firm's specific resources, namely, the impact on internationalization of the stock of social capital and networks; (ii) further research the relationship between international diversification and ownership and control structure, covering a longer period and studying the wine sector in other European countries; iii) analyze in a case by case approach the growth path of the firms, that is, their timing of internationalization in relation to other strategic alternatives.

In summary, the results of this paper allow to conclude that the degree of internationalization is influenced not only by firm-specific characteristics, such as leverage or size, but also by the ownership structure and control. We hope this study stimulates future research on this still highly unexplored topic of family firms' processes of internationalization.

\section{REFERENCES}

Aggarwal, R. and Samwick, A. (2003), "Why do managers diversify their firms? Agency reconsidered", Journal of Finance, Vol. 58, No. 1, pp. 71-118.

Amihud, Y. and Kamin, J. (1979), "Revenue vs. profit maximization: Differences in behavior by the type of control and by market power", Southern Economic Journal, Vol. 45, No. 3, pp. $838-846$.

Amihud, Y. and Lev, B. (1981), "Risk reduction as a managerial motive for conglomerate mergers", Bell Journal of Economics, Vol. 12, No. 2, pp. 605-617.

Anderson, R., Mansi, S. and Reeb, D. (2003), "Founding family ownership and the agency cost of debt", Journal of Financial Economics, Vol. 68, No. 2, pp. 263-285. 
Anderson, R. and Reeb, D. (2003), "Founding-family ownership and firm performance: Evidence from the S\&P500", Journal of Finance, Vol. 58, No. 3, pp. 1321-1328.

Astrachan J., Klein, S. and Smyrnios, K. (2002), "The F-PEC scale of family influence: a proposal for solving the family business definition problem", Family Business Review, Vol. 15, No. 1, pp. 45-58.

Bausch, A. and Krist, M. (2007), "The effect of context-related moderators on the internationalization-performance relationship: Evidence from meta-analysis", Management International Review, Vol. 47, No. 3, pp. 319-347.

Blanco, V., De Quevedo, E. and Delgado, J. (2009), "La estructura financiera de la empresa familiar y el cambio generacional", Revista Española de Financiación y Contabilidad, Vol. 38, No. 141 , pp. 57-73.

Buck, T., Filatotchev, I., Wright, M. and Dyomina, N. (2003), "Insider ownership, human resource strategies and performance in a transition economy", Journal of International Business Studies, Vol. 34, No. 6, pp. 530-549.

Buckley, P. and Casson, M. (1976), The Future of the Multinational Enterprise, Macmillan, Basingstoke.

Calof, J. (1994), "The relationship between firm size and export behavior revisited", Journal of International Business Studies, Vol. 25, No. 2, pp. 367-387.

Carr, C. and Bateman, S. (2009), "International strategy configurations of the world's top family firms", Management International Review, Vol. 49, No. 6, pp. 733-758.

Claver, E., Rienda, L. and Quer, D. (2009), "Family firms' international commitment: The influence of family-related factors", Family Business Review, Vol. 22, No. 2, pp. 125-135.

Denis, D., Denis, D. and Sarin, A. (1997), “Agency problems, equity ownership, and corporate diversification", Journal of Finance, Vol. 52, No. 1, pp. 135-160.

Denis, D., Denis, D. and Sarin, A. (1999), "Agency theory and the influence of equity ownership structure on corporate diversification strategies", Strategic Management Journal, Vol. 20, No. 11, pp. 1071-1076.

Denis, D., Denis, D. and Yost, K. (2002), "Global diversification, industrial diversification, and firm value", Journal of Finance, Vol. 57, No. 5, pp. 1951-1979.

Dunning, J. (1980), "Towards an eclectic theory of international production: Some empirical tests", Journal of International Business Studies, Vol. 11, No. 1, pp. 9-31.

European Commission (2009), Overview of family-business-relevant issues: research, networks, policy measures and existing studies, Directorate-general for Enterprise and Industry: Brussels. Fernández, Z. and Nieto, M. (2005), "Internationalization strategy of small and medium-sized family businesses: some influential factors", Family Business Review, Vol. 18, No. 1, pp. 77-89. 
Filatotchev, I., Stephan, J. and Jindra, B. (2008), "Ownership structure, strategic controls and exporting of foreign-invested firms in transition economies", Journal of International Business Studies, Vol. 39, No. 7, pp. 1133-1148.

Francioni, B., Vissak, T. and Musso, F. (2017), "Small Italian wine producers' internationalization: the role of network relationships in the emergence of late starters", International Business Review, Vol. 26, No. 1, pp. 12-22.

Gallo, M., Tàpies, J. and Cappuyns, K. (2004), “Comparison of family and nonfamily business: Financial logic and personal preferences", Family Business Review, Vol. 17, No. 4, pp. 303-318. George, G., Wiklund, J. and Zahra, S. (2005), "Ownership and the internationalization of small firms", Journal of Management, Vol. 31, No. 2, pp. 210-233.

Gomez-Mejia, L., Makri, M. and Kintana, M. (2010), "Diversification decisions in family-controlled firms", Journal of Management Studies, Vol. 47, No. 2, pp. 223-252.

Graves, C. and Thomas, J. (2004), “Internationalisation of the family business: A longitudinal perspective”, International Journal of Globalisation and Small Business, Vol. 1, No. 1, pp. 727.

Graves, C. and Thomas, J. (2006), "Internationalization of Australian family firms: A managerial capabilities perspective", Family Business Review, Vol. 19, No. 3, pp. 207-224.

Gujarati, D. and Porter, D. (2008), Basic Econometrics, $5^{\text {th }}$ edition, McGraw-Hill: Irwin.

Harris, M. and Raviv, A. (1991), "The theory of capital structure", Journal of Finance, Vol. 46, No. 1, pp. 297-355.

Hennart, J. (1982), A Theory of Multinational Enterprise, University of Michigan, Ann Arbor.

Hitt, M., Tihanyi, L., Miller, T. and Connelly, B. (2006), "International diversification: Antecedents, outcomes and moderators", Journal of Management, Vol. 32, No. 6, pp. 831-867. Jensen, M. (1986), "Agency costs of free cash flow, corporate finance and takeover", American Economic Review, Vol. 76, pp. 323-329.

Jensen, M. and Meckling, W. (1976), "Agency costs and the theory of the firm", Journal of Financial Economics, Vol. 3, No. 4, pp. 305-360.

Johanson, J. and Vahlne, J.-E. (1977), "The internationalization process of the firm: A model of knowledge development and increasing foreign market commitments", Journal of International Business Studies, Vol. 8, No. 1, pp. 23-32.

Kim, W. (1989), "Developing a global diversification measure”, Management Science, Vol. 35, No. 3, pp. 376-383.

Klein, S. (2000), "Family businesses in Germany: significance and structure", Family Business Review, Vol. 13, No. 3, pp. 157-181.

Kontinen, T. and Ojala, A. (2010), "The internationalization of family businesses: A review of extant research", Journal of Family Business Strategy, Vol. 1, No. 2, pp. 97-107. 
Kontinen, T. and Ojala, A. (2011), "International opportunity recognition among small and medium-sized family firms", Journal of Small Business Management, Vol. 49, No. 3, pp. 490514.

Kwok, C. and Reeb, D. (2000), "Internationalization and firm risk: An upstream-downstream hypothesis", Journal of International Business Studies, Vol. 31, No. 4, pp. 611-629.

Leonidou, L. (2004), "An analysis of the barriers hindering small business export development”, Journal of Small Business Management, Vol. 42, No. 3, pp. 279-302.

Leonidou, L., Katsikeas, C., Palihawadana, D. and Spyropoulu, S. (2007), “An analytical review of the factors stimulating smaller firms to export", International Marketing Review, Vol. 24, No. 6, pp. 735-770.

López-Gracia, J. and Aybar-Arias, C. (2000), "An empirical approach to the financial behaviour of small and medium sized companies", Small Business Economics, Vol. 14, No. 1, pp. 55-63.

Lussier, R. and Sonfield, M. (2009), "Founder influences in family businesses: Analyzing combined data from six diverse countries", Journal of Small Business Strategy, Vol. 20, No. 1, pp. 103-118.

Majocchi, A. and Strange, R. (2012), "International diversification: the impact of ownership structure, the market for corporate control and board independence", Management International Review, Vol. 52, No. 6, pp. 879-900.

Manolova, T., Brush, C., Edelman, L. and Greene, P. (2002), "Internationalization of small firms: Personal factors revisited”, International Small Business Journal, Vol. 20, No. 1, pp. 931.

Maurel, C. (2009), "Determinants of export performance in French wine SMEs", International Journal of Wine Business Research, Vol. 21, No. 2, pp. 118-142.

Menendez-Requejo, S. (2005), "Growth and internationalisation of family businesses", International Journal of Globalisation and Small Business, Vol. 1, No. 2, pp. 122-133.

Miller, D., Le Breton-Miller, I. and Lester, R. (2010), "Family and lone founder ownership and strategic behaviour: Social context, identity, and institutional logics", Journal of Management Studies, Vol. 48, No. 1, pp. 1-25.

Mitter, C., Duller, C., Feldbauer-Durstmüller, B. and Kraus, S. (2014), "Internationalization of family firms: the effect of ownership and governance", Review of Managerial Science, Vol. 8, No. 1, pp. 1-28.

Muecke, T. (2008), "The internationalization of wine business: exploitation of social capital", Conference Proceedings of the $4^{\text {th }}$ International Conference of the Academy of Wine Business Research, Siena - Italy.

Oesterle, M., Richta, H. and Fisch, J. (2013), "The influence of ownership structure on internationalization", International Business Review, Vol. 22, No. 1, pp. 187-201. 
Pukall, T. and Calabrò, A. (2014), "The Internationalization of Family Firms: A Critical Review and Integrative Model”, Family Business Review, Vol. 27, No. 2, pp. 103-125.

Remaud, H. and Couderc, J. (2006), "Wine business practices: A new versus old wine world perspective", Agribusiness, Vol. 22, No. 3, pp. 405-416.

Rocco, V. (1996), “Going global: A CEO's perspective", Journal of Management in Engineering, Vol. 12, No. 2, pp. 21-24.

Rugman, A. (1976), "Risk reduction by international diversification", Journal of International Business Studies, Vol. 7, No. 2, pp. 75-80.

Rugman, A. (1981), Inside the Multinationals: The economics of internal markets. Columbia University Press, New York.

Rugman, A. and Verbeke, A. (2004), "A perspective on regional and global strategies of multinational enterprises”, Journal of International Business Studies, Vol. 35, No. 1, pp. 3-18.

Sciascia, S., Mazzola, P., Astrachan, J. and Pieper, T. (2012), "The role of family ownership in international entrepreneurship: Exploring nonlinear effects", Small Business Economics, Vol. 38, No. 1, pp. 15-31.

Seifert, B., Gonenc, H. and Wright, J. (2005), "The international evidence on performance and equity ownership by insiders, blockholders, and institutions", Journal of Multinational Financial Management, Vol. 15, No. 2, pp. 171-191.

Shleifer, A. and Vishny, R. (1986), "Large shareholders and corporate control", The Journal of Political Economy, Vol. 94, No. 3(1), pp. 461-488.

Svinth, R. and Vinton, K. (1993), "Do family-owned businesses have a strategic advantage in international joint ventures?", Family Business Review, Vol. 6, No. 1, pp. 19-30.Tsang, E. (2002), "Learning from overseas venturing experience: The case of Chinese family businesses", Journal of Business Venturing, Vol. 17, No. 1, pp. 21-40.

Zaheer, S. (1995), "Overcoming the liability of foreignness", Academy of Management Journal, Vol. 38, No. 2, pp. 341-363.

Zahra, S. (2003), "International expansion of US manufacturing family businesses: The effect of ownership and involvement", Journal of Business Venturing, Vol. 18, No. 4, pp. 495-512.

Zahra, S. (2005), "Entrepreneurial risk taking in family firms", Family Business Review, Vol. 18, No. 1, pp. 23-40.

Zahra, S., Neubaum, D. and Naldi, L. (2007), "The effects of ownership and governance on SMEs' international knowledge-based resources", Small Business Economics, Vol. 29, No. 3, pp. 309-327. 